\title{
Q\&A
}

Katri Valkokari

\section{Q. In the Innovation Game, Why Do So Many Companies Stay on the Sidelines?}

\begin{abstract}
A. In today's global business environment, innovation is an extreme sport, where teammates, opponents, the playing field, and the rules of the game change all the time. In order to succeed, companies have to be highly skilled and react quickly to these changes - but more importantly - success depends on actually playing the game, not watching from the sidelines.
\end{abstract}

As research during the past several decades has shown, the innovation game increasingly depends on collaboration between players, for example with innovation driven by lead users (von Hippel, 1986), open innovation (Chesbrough, 2003), and co-innovation with several players (von Hippel et al., 2011, Lee et al., 2012). Still, although there are greater opportunities to develop new successful innovations by means of collaboration, such approaches also bring new risks (Pisano \& Teece, 1989), which undermine a company's intention to collaborate. Such risks include loss of knowledge, higher coordination costs, as well as loss of control and higher complexity. The "not invented here" syndrome is another typical reason for staying on the sidelines of the innovation game (Chesbrough \& Crowther, 2006). Furthermore, especially in small and medium-sized enterprises (SMEs) quite practical reasons such as challenges in finding the right partner, identifying relevant external knowledge sources, imbalance between innovation activities and daily business, or insufficient time and financial resources, hinder their participation.

Among both academics and practitioners, the collaborative innovation models are increasingly better understood, and companies are increasingly aware that they can benefit from such collaborations, whether it is among fore-runner companies such as Procter \& Gamble or LEGO or among agile startup firms (Muegge, 2013) or open source communities within software industry (West \& Callagher, 2006). Thus, regarding more traditional industries, it is also important to notice that an innovation model of co-creation of immaterial products, such as software, cannot be directly adapted to innovation in physical production (Bauwens, 2009).
But, given that around one third of innovating companies drew upon external development or knowledge sources from 2010 to 2012 (OECD, 2015), there are still many, many companies sitting on the bench and just watching the innovation game. There is also significant effect of firm size when collaborating on innovation: large firms are usually two to three times more likely to engage in collaboration than SMEs (OECD, 2015). These firms, still sitting on the sidelines, are either doubting that it would work for them or stalling because they just do not know how to actually start playing the game or cannot figure out with whom they should play. And so, a key future challenge is to help companies make the leap from sidelines to playing field so that they may reap the rewards of collaborative innovation.

In business, success rarely comes in the form of winning the game - success means you are able to keep playing. But, losses are common. In many cases, companies lose when they fail to adapt. Traditional players may enjoy great success for some time and then fail to adapt to changes, for example, because their playing style stagnates; they become locked in to key personnel, strategies, information flows, norms, and mental models. Then, new players may come from unexpected directions and with new playbooks. They are not creating entirely new games, but rapidly attacking to the gameplan of traditional players by using, for instance, new combinations of superior technology and compelling customer experience. There are several examples of how established corporations, for example Nokia, Blackberry, and Kodak, have quite suddenly found themselves unable to adapt. When this happens, the innovation game can be unforgiving.

Companies must be prepared for setbacks, but the risks are greater if they choose not to innovate. They must accept that the innovation game comes with risk, and they must be prepared to change their way of thinking, and not only among the coaching staff, because innovation is a team sport. Innovation should be a part of every employee's work, not only of those working in an $R \& D$ department or on the front lines of business development (Lafley \& Charan, 2008). 


\section{Q\&A. In the Innovation Game, Why Do So Many Companies Stay on the Sidelines?} Katri Valkokari

But, even if a company is aware of the benefits, accepts the risks, and is ready to take on the challenge of moving from the sidelines to the playing field, several key questions remain:

\section{Where should they play?}

2. With whom should they play?

\section{How should they play?}

\section{Where to play}

The answer to the question of where to play often depends on the nature of the business. One option is to seek out innovation centres or platforms that facilitate collaboration between different players, such startups, venture capitalists, accelerators, vendors, and academic institutions. Global technology hubs are the preferred destinations for setting up innovation centers. For instance, $60 \%$ of companies that have set up these centres have a presence in Silicon Valley (Capgemini, 2015). In many sectors, the locus of the innovation game is changing from local or regional places to virtual spaces and platforms (Muegge, 2013). When operating on large geographical scales, for instance, when exclusively using Internet platforms, the levels of interaction and collaboration between the players in the innovation game may remain low. Therefore new ways to integrate global and local playgrounds - physical and virtual meeting places - is required.

The global playing field creates powerful opportunities for players to access far-away markets and scale quickly, right from a company's inception, as evidenced by "born global" firms (Rasmussen \& Tanev, 2015; Tanev, 2013). However, companies may find that their local playing field contains valuable opportunities and relationships. In the special issue of the TIM Review on "local open innovation" (timreview.ca/ issue $/ 2013 / \mathrm{march}$ ), the focus was on the local game - meeting nearby players and learning how their skills can complement your own game. With local open innovation, Deutsch and Dancause (2013) stress the importance of fostering: i) input from "unobvious" sources; ii) informal relationships and interactions; and iii) serendipity. Similarly, living labs provide ready-made real-life environments for companies to interact with users and other stakeholders to create unforeseeable innovations (Leminen, 2015). Ultimately, the challenge focuses on how quickly ideas can be tried out and changes can be made, therefore the emphasis has been on rapid experiments, simulations, and pilots. These approaches make it easier for companies to step off the sidelines and get into the game so that they may benefit from new models of innovation.

With whom to play

Market sources, including other companies (e.g., suppliers), customers, or competitors, are the traditional sources of external knowledge and the most typical even today (OECD, 2015). Especially in R\&D gate models and processes, early involvement of suppliers (ESI) models are an actively discussed phenomenon (Bidault et al., 1998; Johnsen, 2009). On the other hand, the service literature emphasizes service co-creation with customers (Hakanen \& Jaakkola, 2012; Vargo \& Lusch, 2008). Ever since von Hippel (1986) introduced the concept of a "lead user", there has been much discussion about the benefits of empowering consumers and end users to participate in innovation processes. Subsequently, innovation researchers have distinguished different collaboration models such as customer-focused innovation, customer-centred innovation, and customer-driven innovation (Desouza et al., 2008).Thus, larger companies are two or three times more likely to collaborate with research institutes or higher-education institutions than SMEs (OECD, 2015), meaning that larger companies have more experience in with different playing fields as well as with different players.

In today's networked economy, the boundary between a customer and a supplier is "fuzzy" or unclear - especially regarding the innovation and exploration of new knowledge (Paasi et al., 2010) and the importance of including other stakeholders is now recognized (Pedrosa, 2009). In the innovation game, these relationships with other players are dynamic: when the game suddenly changes, it may also mean that the customers or suppliers change. Still, the literature on inter-organizational relationships often highlights how relationship building and network management are longitudinal tasks, although these arrangements should be distinguished from companies by their temporality (Halinen et al., 2012).

In this fast-changing game, companies must consider how they are perceived by other players. One way to survive and succeed in the innovation game is to be an attractive team member. Companies need to continually strengthen their network positions and keeps themselves and their employees sharp. The key is to develop specific capabilities and clearly communicate your needs to other players who may become collaborators. 


\section{Q\&A. In the Innovation Game, Why Do So Many Companies Stay on the Sidelines?} Katri Valkokari

And, as shown in the previous section, the choice of where to play affects who is available to play, whether it finding a global partner through an international innovation platform or getting out and meeting a helpful "neighbour" with complementary skills and needs. New types of players and coaches, such as open innovation service provider and other intermediators, can also help to play the game. It is important to look beyond the usual suspects and find new collaborators (Deutsch \& Dancause, (2013). Both researchers and practitioners can also find new ways to involve all players in the innovation game: everyone will benefit if we can encourage the ones who are now sitting on the bench.

\section{How to play}

The innovation game is changing all the time. When players make decisions and calculate future alternatives, they are looking forwards. However, the future is always uncertain, and the game can really only be understood when looking backwards and reflecting on the moves made by each player and the consequences. Instead of aiming to avoid uncertainty, players must be flexible and prepared to make adjustments; the connectivity with other players implies that a decision or action by one influences all others, but not in any uniform manner. The results of the game appear from the dynamics of strategic manoeuvring amongst players, and therefore the key success factor is the player's ability to manage dynamic strategic interactions related to innovation (Aveni, 1997). This ability can be enhanced by studying the game and the behaviours of other players, and continually learning how to be a better player.

Innovative and future-focused players seek opportunities to maximize communication and interaction among actors in order to create knowledge synergies and new business opportunities. The practical challenge is to master a strategy of "plug, play, and repeat":

1. Plug: quickly find new unknown collaboration parties and evaluate them.

2. Play: configure collaborative settings that encourage players to work towards shared purposes, with enthusiasm.

3. Repeat: the game can change at any minute, so players must be prepared to repeat the "plug" and "play" steps with new partners working towards new goals.

This new approach encourages preparation and flexibility, but is not easy and it may take some companies far out of their traditional comfort zone. The new maps for searching business opportunities may be based on the connections rather than locations and their distances. The connections are built on different exchanges of, for example, information, money, resources, or social relationships.

\section{Future research}

To help more companies step onto the playing field, there are several areas that should be researched to complement our current understanding on how to play the innovation game.

First, given that knowledge is highly dispersed and complexity grows all the time, new sources of innovation are required. New players are needed and companies must search hard both locally and globally for problem solvers, and they must be prepared to collaborate with previously unknown partners.

Second, in addition to formal intellectual property rights, tacit knowledge will play a key role as the need to share (or protect) different knowledge sources increases. Furthermore, players should also be able to find the dark side of their knowledge base: knowing what questions that they are not able to answer.

Third, companies require several playbooks, or innovation models, to be used concurrently as they fit their strategies to different games and goals. For instance, companies are simultaneously connected to the global economy and its specific rules as well as social networks and communities, which operate by different sets of rules. Further research and insights from practice are needed to help companies develop their own style of "plug, play, and repeat" strategies.

Finally, to help companies feel confident enough to join the game, there needs to be further research about how exactly to change mindsets, meet potential collaborators (who may be unknown), figure out quickly if they are a good fit and can be trusted, and then lead the enthusiasm. A promising research approach to futureoriented innovation games follows system theory thinking (e.g., Ashby, 1958; Luhmann, 1995) and is based on systemic and practice-based approaches (Valkokari et al., 2011). According to this approach, the continuous change can be seen as ongoing improvisation: the innovation players' readiness to constantly disrupt themselves through strategizing and organizing within the innovation game. Thus, making game-specific decisions requires local and experiential knowledge, which can be gained only by playing the game. And the game cannot be played from the sidelines. 


\section{Q\&A. In the Innovation Game, Why Do So Many Companies Stay on the Sidelines?} Katri Valkokari

\section{About the Author}

Katri Valkokari works as a Principal Scientist at VTT (Technical Research Centre of Finland) in the Business Ecosystems, Value Chains and Foresight research area. Over the past 15 years, she has carried out several development projects concerning different networked business arrangements (ecosystems, networks, partnerships, and firms). In 2009, Katri completed her doctoral thesis on business network development. She has published several international and national articles in the research areas of business network management, collaboration, organizational knowledge, and innovation management.

\section{Acknowledgements}

The author would like to thank both the anonymous reviewer and the editor, whose comments helped clarify the focus of the article. This work is part of the research program "Towards Relational Business Practices" (REBUS), which is one of the research programs of the Finnish Metals and Engineering Competence Cluster, FIMECC.

\section{References}

Ashby, W. R. 1958. An Introduction to Cybernetics. New York: Wiley

Aveni, R. A. 1997. Waking Up to the New Era of Hypercompetition. The Washington Quarterly, 21(1): 183-195.

Bauwens, M. 2009. Class and Capital in Peer Production. Capital \& Class, 23 (1): 121-141.

http://dx.doi.org/10.1177/030981680909700107

Bidault, F., Despres, C., \& Butler, C. 1998. Leveraged Innovation: Unlocking the Innovation Potential of Strategic Supply. Basingstoke, UK: Macmillan.

Deutsch, C., \& Dancause, P. 2013. TIM Lecture Series - Local Open Innovation and the Seeking Solutions Approach. Technology Innovation Management Review, 3(3): 42-46.

http://timreview.ca/article/669

Desouza, K.C., Awazu, Y., Jha, S., Dombrowski, C., Papagari, S., Baloh, P., \& Kim, J. Y. 2008. Customer-Driven Innovation. Research-Technology Management, 51(3): 35-44.

Capgemini Consulting. 2015. The Innovation Game: Why and How Businesses are Investing in Innovation Centers. Paris: Capgemini Consulting.
Chesbrough, H. \& Crowther, A. 2006. Beyond High Tech: Early Adopters of Open Innovation in Other Industries. $R \& D$ Management, 36(3): 229-236.

http://dx.doi.org/10.1111/j.1467-9310.2006.00428.x

Chesbrough, H. 2003. Open Innovation: The New Imperative for Creating and Profiting from Technology. Boston, MA: Harvard Business School Press.

Halinen, A., Medlin, C. J. \& Törnroos, J.-Å. 2012. Time and Process in Business Network Research. Industrial Marketing Management, 41(2): 215-223.

http://dx.doi.org/10.1016/j.indmarman.2012.01.006

Hakanen, T. \& Jaakkola, E. 2012. Co-Creating Customer-Focused Solutions within Business Networks: A Service Perspective. Journal of Service Management, 23(4): 593-611. http://dx.doi.org/10.1108/09564231211260431

Johnsen, T. E. 2009. Supplier Involvement in New Product Development and Innovation: Taking Stock and Looking to the Future. Journal of Purchasing and Supply Management, 15(3): 187-197. http://dx.doi.org/10.1016/j.pursup.2009.03.008

Lafley, A. G. \& Charan, R. 2008. The Game-Changer: How You Can Drive Revenue and Profit Growth with Innovation. New York: Crown Business.

Lee, S. M., Olson, D. L. \& Trimi, S. 2012. Co-Innovation: Convergenomics, Collaboration, and Co-Creation for Organizational Values. Management Decision, 50(5): 817-831. http://dx.doi.org/10.1108/00251741211227528

Leminen, S. 2015. Q\&A. What Are Living Labs? Technology Innovation Management Review, 5(9): 29-35. http://timreview.ca/article/928

Luhmann, N. 1995. Social Systems. Palo Alto, CA: Stanford University Press.

Muegge, S. 2013. Platforms, Communities, and Business Ecosystems: Lessons Learned about Technology Entrepreneurship in an Interconnected World. Technology Innovation Management Review, 3(2): 5-15. http://timreview.ca/article/655

OECD. 2015. OECD Science, Technology and Innovation Scoreboard 2015: Innovation for Growth and Society. Paris: Organisation for Economic Co-operation and Development (OECD) Publishing. http://dx.doi.org/10.1787/sti_scoreboard-2015-en

Paasi, J., Luoma, T., Valkokari, K., \& Lee, N. 2010. Knowledge and Intellectual Property Management in Customer-Supplier Relationships. International Journal of Innovation Management, 14(4): 629-654.

http://dx.doi.org/10.1142/S1363919610002805

Pedrosa, A. 2009. Motivating Stakeholders for Co-created Innovation. Open Source Business Resource, December 2009: 35-39. http://timreview.ca/article/311

Pisano, G. \& Teece, D. 1989. Collaborative Arrangements and Global Technology Strategy: Some Evidence from the Telecommunications Equipment Industry. Research on Technological Innovation, Management and Policy, 4: 227-256. 


\section{Q\&A. In the Innovation Game, Why Do So Many Companies Stay on the Sidelines?}

\section{Katri Valkokari}

Rasmussen, E. A., \& Tanev, S. 2015. The Emergence of the Lean Global Startup as a New Type of Firm. Technology Innovation Management Review, 5(11): 12-19.

http://timreview.ca/article/941

Rogers, E. M. 1983. Diffusion of Innovations (3rd ed.). New York: The Free Press.

Tanev, S. 2012. Global from the Start: The Characteristics of BornGlobal Firms in the Technology Sector. Technology Innovation Management Review, 2(3): 5-8.

http://timreview.ca/article/532

Valkokari, K., Koivisto, T., Hyötyläinen, R., Heikkinen, M., Simons, M., Nuutinen, M., Apilo, T., \& Oksanen, J. 2011. Management of Future Innovative Firms and Networks. VTT Research Notes: 2594. Espoo, Finland: VTT.

http://www.vtt.fi/inf/pdf/tiedotteet/2011/T2594.pdf
Vargo, S. L. \& Lusch, R. F. 2008. Service-Dominant Logic: Continuing the Evolution. Journal of the Academy of Marketing Science, 36(1): $1-10$. http://dx.doi.org/10.1007/s11747-007-0069-6

von Hippel, E. 1986. Lead Users: A Source of Novel Product Concepts. Management Science, 32(7): 791-805. http://dx.doi.org/10.1287/mnsc.32.7.791

von Hippel, E., Ozawa, S. \& De Jong, J. 2011. The Age of the ConsumerInnovator. MIT Sloan Management Review, Fall 2011: 27-35.

West, J. \& Gallagher, S. 2006. Challenges of Open Innovation: The Paradox of Firm Investment in Open-Source Software, $R \& D$ Management, 36(3): 319-331. http://dx.doi.org/10.1111/j.1467-9310.2006.00436.x

Citation: Valkokari, K. 2015. Q\&A. In the Innovation Game, Why Do So Many Companies Stay on the Sidelines? Technology Innovation

Management Review, 5(11):35-39. http://timreview.ca/article/944

Keywords: innovation, open innovation, collaboration, lead users, co-innovation, co-creation, open source 